\title{
The effect of storage time and egg weight at room temperature on interior quality of hatching egg in Magelang duck
}

\author{
Muhammad Fahri $^{1 *}$, Edy Kurnianto ${ }^{1)}$, and Edjeng Suprijatna ${ }^{1)}$ \\ ${ }^{1)}$ Faculty of Animal and Agricultural Sciences University of Diponegoro, Semarang 50275
}

Submitted: 30 May 2019, Accepted: 04 October 2019

\begin{abstract}
The objective of this study was to examine the effect of storage time and egg weight at room temperature on the interior quality of Magelang duck. The material used were 120 eggs of Magelang duck. The parameters observed were albumen index, egg yolk index and Haugh unit. The 4 $x 3$ factorial experiment with 2 factors was applied. In which the first factor (A) was the length of egg storage of: $\mathrm{a} 1=1$ day, $\mathrm{a} 2=3$ days, $\mathrm{a} 3=5$ days and $\mathrm{a} 4=7$ days and the second factor $(\mathrm{B})$ was egg weight of b1 (low $=48,4 \mathrm{~g}-63,1 \mathrm{~g}$ ) b2 (medium $=63,2 \mathrm{~g}-73,6 \mathrm{~g}$ ) and b3 (high 73,7g-81g,). The data were analyzed by the General Linear Model (GLM) procedure of Statistical Analysis System (SAS). The result showed that there was no interaction between storage time and egg weight on quality interior. Storage time was significant different $(\mathrm{P}<0,05)$ on albumin index, egg yolk index and Haugh unit. Egg weight had no effect on index albumen, egg yolk index and Haugh unit. In conclusion, the quality of the interior began to decline after being saved 3 days and the optimal egg weight for hatching eggs is medium egg weight.
\end{abstract}

Keywords: egg weight; interior quality; Magelang duck; storage time.

*Corresponding Author: muhammadfahri678@gmail.com 


\section{INTRODUCTION}

Magelang duck is a local Indonesian duck as genetic resources that has different characteristics from other local ducks. The qualitative characteristics of Magelang ducks include brown colored feathers, white necklace on the neck, bluish-green eggshell color, straight body shape for female and slim for male and walk upright. Magelang duck reach puberty at 5-6 months (Kementerian Pertanian, 2013). Magelang duck is a dual-purpose raised for the eggs and meat. Magelang duck has an important role because of high egg production (48$70 \%$ ), and if they maintained intensively the egg production can reach $80 \%$ (Yuniwarti and Muliani, 2014). Magelang duck egg weight ranged from $60 \mathrm{~g}-70 \mathrm{~g}$ with a total production of 200-300 eggs per year (Kementerian Pertanian, 2013).

Magelang duck ability is not only on the egg production, but also on the hatching percentage. The success of hatched eggs can also be seen in the egg quality. The quality of eggs was categorized in both exterior and interior quality. Exterior quality is egg shape, egg surface area and egg weight. The heavier eggs, the larger egg surface (Adamski et al., 2005). The more surface area of the egg, the more the pores of the shells, so that the release of $\mathrm{CO} 2$ in the egg occurs more quickly during the egg storage. It will reduce the quality of the egg (Sekeroglu et al., 2016).

The interior quality of eggs can be seen in the quality of the white and yolk. The quality of the interior will decrease in parallel to long duration of egg storage. The reduced quality of egg white is caused by the evaporation of $\mathrm{CO} 2$ through the pores of the shells, resulting in the degradation of organic matter in egg whites such as $\mathrm{CO} 2$, $\mathrm{NH} 3$, and N2. Then, this condition results in decreased egg white consistency, moreover then the egg becomes runny (Sudaryani, 2003). Meanwhile, the decreasing quality of the yolk eggs during storage is caused by damage to the vitelin membrane because of diffusion of water from the egg white into the yolk (Purwadi et al., 2017).

The value of egg white index is determined by comparing the height of the white to the diameter of the thick egg white. This value will decrease during storage (Swacita and Cipta, 2011). The decline in the value of the white index is caused by the evaporation of $\mathrm{CO} 2$ and $\mathrm{H} 2 \mathrm{O}$ that occurs through pores in eggshells (Septiana et al., 2015).

The yolk index value is known by comparing the height of the yolk to the diameter of the yolk. Yolk index value of $0.33-0.50$ with an average of 0.42 is a good quality of egg yolk (Swacita and Cipta, 2011). The higher egg yolk and the shorter yolk diameter are better yolk index (Sulistina et al., 2017).

Haugh Unit (HU) is the one of way to find out the egg interior quality. Good egg quality has high egg white, so that it has high HU value (Sulistina et al., 2017). Good quality eggs have a $\mathrm{HU}$ value of 75 , whereas broken eggs have HU was lower than 50 (Swacita and Cipta, 2011).

The purpose of this study was to examine the effect of storage time and egg weight at room temperature on the interior quality of Magelang duck eggs. The benefit of this study was to provide information on the presence or absence of the effects of storage time and egg weight at room temperature on the interior quality of Magelang duck eggs.

\section{MATERIALS AND METHODS}

This study was carried out at the NonRuminant Animal Breeding and Breeding Office of the Banyubiru Duck Work Unit, Ngrapah Village, Banyubiru Subdistrict, Semarang Regency, Central Java.

\section{Material}

Research material used were 120 Magelang duck eggs. The tools used were calipers, depth micrometers, analytical scales with accuracy 0.0001 g (Sayaki R.) 


\section{Method}

Duck eggs in this study originated from duck female raised with males in a mating ratio of males to females was 2:10. Duck eggs obtained were divided into 3 groups of eggs, namely light, medium and heavy eggs, then eggs were stored for 1,3 , 5 , and 7 days at room temperature. After storage, the eggs were weighed to find out the weight loss during storage. Then, the eggs were broken down and observations were conducted on the white and yolk parts. Breaking the eggs was done for 10 periods. The design applied was a completely randomized with $4 \times 3$ factorial design using 10 replications. The study used two treatment factors, in which the first factor (A) was the duration of egg storage, namely: a1 $=1$ day, $\mathrm{a} 2=3$ days, $\mathrm{a} 3=5$ days and a 4 $=7$ days and the second factor (B) was egg weight, b1 (light $=48.4 \mathrm{~g}-63.1 \mathrm{~g}$,) b2 (medium $=63.2 \mathrm{~g}-73.6 \mathrm{~g})$ and b3 (weight $=$ $73.7 \mathrm{~g}-81 \mathrm{~g}$,). The parameters observed included the index of egg whites, index of yolk and Haugh Unit. The formula for egg white index, egg yolk index, and Haugh unit (Laily and Suhendra, 1978) were as follows:

$$
\begin{gathered}
\text { Egg white index }= \\
\text { egg white height } \\
\left.\frac{1}{2} \text { (egg white width }+ \text { egg white length }\right) \\
\text { Egg yolk index }= \\
\frac{\text { egg yolk height }}{\text { egg yolk diameter }} \\
\text { Haugh unit }= \\
100 \log \left(\mathrm{H}+7,57-1,7 \mathrm{~W}^{0,37}\right)
\end{gathered}
$$

Where :

$\mathrm{H}=$ Egg white high

$\mathrm{W}=$ Egg weight

\section{Data Analysis}

The data obtained were analyzed using the General Linear Model (GLM) Statistical Analysis System (SAS) v6.12 programme. If there was an influence between egg storage time-egg weight and interior quality of the hatched eggs, then it was continued by analysis using Duncan's New Multiple Range Test

\section{RESULTS AND DISCUSSION Egg White Index}

Egg storage time and egg weight did not have interactions. The egg storage time in this study had a significant effect $\mathrm{P}<0.05$ ) reduced the egg white index, while the egg weight did not affect the egg white index (Table 1). condition was up to 5 days of storage time and started bad after 7 days of storage. According to Swacita and Cipta (2011), the $0.05-0.17$ is a good white index value. Good hatching eggs should not be stored for 7 days, because after hatching eggs were stored up to 7 days, it could reduce hatchability. The average egg white index in good According to Dewanti et al. (2014), the hatchability of duck eggs was 70\%-80\%. King'ori (2011) argued that holding eggs for more than 7 days could reduce the hatchability of eggs.

The egg white index value began to decrease after being stored for 3 days. This decrease was faster than compared to Khan et al. (2013), that a decrease in the value of the white index occured at a storage time of 6 days. This difference was influenced by the temperature at which the hatched eggs were stored and the weight of the eggs. According to Garip and Dere (2011), as long as the eggs are stored the egg weight will decrease. This was due to differences in temperature and humidity of the environment where eggs were stored, then eventually it decreased the white index. The index value of egg white was influenced by the thickness of the egg white. The thickness of egg white was affected by ovomucin content.

The better quality of ovomucin, better white egg and it was not runny. According to Raji et al. (2009), the runny egg occured in egg whites was due to the destruction of ovomucin in egg white. The decrease in the egg white index occured because it had 
thinned the egg white. The egg white to be runny occured because ovomucin had been damaged due to the evaporation of $\mathrm{CO}_{2}$ through the pores of the shell during egg storage. According to Septiana et al. (2015), at the 7-day storage period there was evaporation of $\mathrm{CO}_{2}$ and $\mathrm{H}_{2} \mathrm{O}$ through the pores in the eggshell, so that the height of the albumen decreased and then it became runny. Egg weights in this study did not affect the white index value. These results were similar to report of by Ukwu et al. (2017), in which light egg weight, medium or heavy did not affect the white index value. Heavy egg weight after storage for 7 days decreased faster than at light or medium weights. The age of bird, genetic, feed could increase the weight of duck eggs. According to Sekeroglu and Altuntas (2008), egg weight depend on feed, parent age, strain, genetic, and environmental temperature.

Tabel 1. The average value of the egg white index in Magelang duck eggs

\begin{tabular}{ccccc}
\hline \multirow{2}{*}{$\begin{array}{c}\text { Storage time } \\
\text { (day) }\end{array}$} & \multicolumn{3}{c}{ Egg weight $(\mathrm{g})$} & \multirow{2}{*}{ Average } \\
\cline { 2 - 4 } & Light & Medium & Heavy & \\
\hline 1 & $0.073 \pm 0.029$ & $0.075 \pm 0.010$ & $0.076 \pm 0.009$ & $0.075 \pm 0.016^{\mathrm{a}}$ \\
3 & $0.062 \pm 0.022$ & $0.069 \pm 0.012$ & $0.065 \pm 0.012$ & $0.065 \pm 0.015^{\mathrm{b}}$ \\
5 & $0.070 \pm 0.026$ & $0.054 \pm 0.014$ & $0.057 \pm 0.010$ & $0.060 \pm 0.017^{\mathrm{c}}$ \\
7 & $0.052 \pm 0.012$ & $0.052 \pm 0.010$ & $0.043 \pm 0.006$ & $0.049 \pm 0.009^{\mathrm{c}}$ \\
\hline Average & $0.064 \pm 0.022$ & $0.063 \pm 0.012$ & $0.064 \pm 0.009$ & $0.062 \pm 0.014$ \\
\hline
\end{tabular}

$\overline{\text { Different superscripts in the same column show indicates significantly differences }(\mathrm{P}<0,05)}$

\section{Egg Yolk Index}

Egg storage time and egg weight did not have an interaction. The storage time had a significant effect $(\mathrm{P}<0.05)$ on the egg yolk index, while egg weight did not affect egg yolk index (Table 2).

Tabel 2. The average value of yolk index in Magelang duck eggs

\begin{tabular}{ccccc}
\hline $\begin{array}{c}\text { Storage time } \\
\text { (day) }\end{array}$ & \multicolumn{3}{c}{ Egg weight $(\mathrm{g})$} & \multirow{2}{*}{ Average } \\
\cline { 2 - 4 } & Light & Medium & Heavy & \\
\hline 1 & $0.393 \pm 0.010$ & $0.396 \pm 0.024$ & $0.386 \pm 0.027$ & $0.391 \pm 0.020^{\mathrm{a}}$ \\
3 & $0.388 \pm 0.044$ & $0.399 \pm 0.023$ & $0.400 \pm 0.036$ & $0.396 \pm 0.035^{\mathrm{a}}$ \\
5 & $0.430 \pm 0.046$ & $0.370 \pm 0.034$ & $0.374 \pm 0.029$ & $0.391 \pm 0.036^{\mathrm{b}}$ \\
7 & $0.384 \pm 0.049$ & $0.362 \pm 0.023$ & $0.370 \pm 0.025$ & $0.371 \pm 0.032^{\mathrm{b}}$ \\
\hline Average & $0.399 \pm 0.037$ & $0.382 \pm 0.026$ & $0.382 \pm 0.029$ & $0.387 \pm 0.031$ \\
\hline
\end{tabular}

Different superscripts in the same column show indicates significantly differences $(\mathrm{P}<0,05)$

The average yolk index value was still above the standard. This was because eggs were stored for no more than 7 days. According to Swacita and Cipta (2011), a value of $0.33-0.50$ was a good yolk index value. Yolk index values that were below the standard could reduce hatchability. Dewanti et al. (2014) stated that the hatchability of duck eggs ranged from $70 \%$ to $80 \%$. The egg hatchability could be achieved, the quality of egg yolk must be considered. Good quality egg yolk could be achieved by not storing eggs for more than 7 days. Karabayir (2010) showed that better hatchability was observed for up to 7 days storage period. After 7 days of storage, the hatch percentage would decrease. The yolk index value begin to decrease at the storage of 5 days. This result was faster compared to statement of Demirel and Kirikci (2009) that a decrease in the yolk index occurred at 7 days of storage. The difference in decrease in the value of the yolk index was influenced by storage temperature and egg 
weight. Samli et al. (2005) stated that when storage temperatures increased during storage of eggs, it will accour faster decrease in the yolk index.

The yolk index value was influenced by the height of the yolk. The height of the yolk was caused by the elasticity of the vitelin membrane. As storage age increased, the strength of the vitelin membrane decreased. According to Akyurek and Okur (2009), the strength of the vitelin membrane decreased with increasing storage time so as to reduce egg yolk height. The decrease in the value of the yolk index was caused by osmotic pressure so that there was a process of transferring water existed in the egg white into the yolk. According to Demirel and Kirikci (2009), the quality of the yolk index will decrease if the eggs was stored for too long.

Light, medium, and heavy egg weights in this study did not affect the yolk index value. These results were the same as reported by Ukwu et al. (2017) that light, medium and severe egg weight groups did not affect the yolk index value. However, the average weight of eggs was lower than the weight of light eggs. It was stated by Septika et al. (2013) that decreasing egg weight was due to the evaporation process during storage.

\section{Haugh Unit}

Storage time and egg weight did not have an interaction and egg storage time and egg weight significantly affected $(\mathrm{P}<0.05)$ the HU value (Table 3).

Tabel 3. The average value of the Haugh unit in Magelang duck eggs

\begin{tabular}{cllrl}
\hline \multirow{2}{*}{$\begin{array}{c}\text { Storage time } \\
\text { (day) }\end{array}$} & \multicolumn{3}{c}{ Egg weight $(\mathrm{g})$} & \multirow{2}{*}{ Average } \\
\cline { 2 - 4 } & \multicolumn{1}{c}{ Light } & \multicolumn{1}{c}{ Medium } & Heavy & \\
\hline 1 & $69.60 \pm 15.60$ & $73.55 \pm 4.81$ & $72.53 \pm 6.26$ & $71.89 \pm 8.89^{\mathrm{a}}$ \\
3 & $67.89 \pm 8.40$ & $70.62 \pm 6.36$ & $63.79 \pm 8.55$ & $67.43 \pm 7.77^{\mathrm{b}}$ \\
5 & $68.87 \pm 18.83$ & $58.57 \pm 9.63$ & $58.63 \pm 8.16$ & $62.02 \pm 12.21^{\mathrm{c}}$ \\
7 & $55.08 \pm 11.18$ & $55.43 \pm 10.31$ & $42.84 \pm 7.65$ & $51.12 \pm 9.71^{\mathrm{d}}$ \\
\hline Average & $65.36 \pm 13.50$ & $64.54 \pm 7.78$ & $59.45 \pm 7.66$ & $63.13 \pm 9.65$ \\
\hline
\end{tabular}

Different superscripts in the same column show indicates significantly differences $(\mathrm{P}<0,05)$

The average value of the Haugh Unit was still in the normal range $(>50)$. According to Swacita and Cipta (2011), eggs could be stated to be damaged if they had a HU below 50. The value of HU under 50 could reduce hatchability. Subari et al. (2013) duck eggs at one day storage period produced $89.63 \%$ hatchability and 7 days storage time resulted in $70.56 \%$ hatchability. The hatching egg should not be stored for more than 7 days. According to Onbasilar et al. (2007), hatchability begin to decline after eggs was stored for more than 7 days. This was may be because of the increasing embryo death due to water loss and egg white degradation during storage. The value of $\mathrm{HU}$ in this study decreased faster than those stated by Demirel and Kirikci (2009), in which the value of HU begin to decrease at the storage of 6 days. This difference was influenced by storage temperature and egg weight. According to Jin et al. (2011), temperature and storage time greatly affect HU. High storage temperatures for eggs stored before hatching will accelerate the decline in HU.

Egg weight and high egg white affect the HU. The weight of duck eggs and egg white was influenced by the storage temperature and the quality of ovomucin. According to Lestari et al. (2015), good quality ovomucin produced good egg white. The decline in HU was caused by evaporation through the pores of the 
eggshell, which resulted in the destruction of ovomucin fibers. Purdiyanto and Riyadi (2018) stated that $\mathrm{CO}_{2}$ lost through the pores of the shells caused damage to ovomucin fibers, so that the thickness of the egg white would decrease.

Light, medium, and heavy egg weights in this study did not affect the HU value. These results were similar to statement of Ukwu et al. (2017) that light, medium and severe egg weight groups did not affect the HU value. The weight of eggs was lower than that of light or medium eggs. This was because the weight of heavy eggs had a wider surface area, so that the process of losing egg weight due to evaporation occurs faster. According to Sekeroglu et al. (2016), eggs having had large surface area evaporation occur faster. Egg weights above or below the standard used in this study could reduce hatchability. Hassan et al. (2005) stated that the weight egg used for hatching was either not too heavy $(>77 \mathrm{~g})$ or not too light $(<50 \mathrm{~g})$. Factors influencing the weight of eggs that were above or below the standard were the age of the parent, the feed given and genetic. Older parent will produce egg weights tend to be heavier and the lack of feed intake could produce lighter eggs. According to Yuwanta (2004), egg weight was influenced by many factors included genetic, feed, and age of the parent.

\section{CONCLUSION}

Based on the observed parameters, it is concluded that the interior quality began to decrease after being stored for 3 days and the optimal egg weight for hatching eggs was medium egg weight.

\section{REFFERENCES}

Adamski, M., Bernacki, Z., and Kuźniacka, J. (2005). Changes in the biological value of duck eggs defined by egg quality. In Folia Biologica (Vol. 53, pp. 107-114). https://doi.org/10.3409 /173491605775789335
Akyurek, H., and Okur, A. A. (2009). Effect of storage time, temperature and hen age on egg quality in free-range layer hens. Journal of Animal and Veterinary Advances, 8(10), 1953-1958.

Demirel, Ş., and Kirikçi, K. (2009). Effect of different egg storage times on some egg quality characteristics and hatchability of pheasants (Phasianus colchicus). Poultry Science, 88(2), 440-444. https://doi.org/10.3382/ps.2 008-00131

Dewanti, R., Yuhan, and Sudiyono. (2014). Pengaruh bobot dan frekuensi pemutaran telur terhadap fertilitas, daya tetas, dan bobot tetas itik lokal. Buletin Peternakan, 38(1), 16. https:// doi.org/10.21059/buletinpeternak.v3 $8 \mathrm{i} 1.4607$

Garip, M., and Dere, S. (2011). The effect of storage period and temperature on weight loss in quail eggs and the hatching weight of quail chicks. Journal of Animal and Veterinary Advances, 10(18), 2363-2367. https: //doi.org/10.3923/javaa.2011.2363.2367

Hassan, S. M., Siam, A. A., Mady, M. E., and Cartwright, A. L. (2005). Egg storage period and weight effects on hatchability of ostrich (Struthio camelus) eggs. Poultry Science, 84(12), 1908-1912. https://doi.org/10 $.1093 / \mathrm{ps} / 84.12 .1908$

Jin, Y. H., Lee, K. T., Lee, W. I., and Han, Y. K. (2011). Effects of storage temperature and time on the quality of eggs from laying hens at peak production. Asian-Australasian Journal of Animal Sciences, 24(2), 279-284. https://doi.org/10.5713/ajas.2011.10210

Karabayir, A. (2010). Effects of different storage durations of japanese quails (coturnix coturnix japonica) eggs on their hatching chick rates and live weight gains. Journal of Animal and Veterinary Advances, 9(9), 1358-1361. https://doi.org/10.3923/javaa.2010.135 8.1361 
Kementerian Pertanian. (2013). Keputusan Menteri Pertanian Nomor: 701/Kpts/PD.410/2/2013 tentang Penetapan Rumpun Itik Magelang. Jakarta: Kementrian Pertanian.

Khan, M. J. A., Khan, S. H., Bukhsh, A., Abbass, M. I., and Javed, M. (2013). Effect of different storage period on egg weight, internal egg quality and hatchability characteristics of Fayumi eggs. Italian Journal of Animal Science, 12(2), 323-328. https://doi. org/10.4081/ijas.2013.e51

King'ori, A. M. (2011). Review of the factors that influence egg fertility and hatchabilty in poultry. International Journal of Poultry Science, 10(6), 483-492. https://doi.org/10.3923/ijps .2011 .483 .492

Laily, R. A., and Suhendra, P. (1978). Teknologi Hasil Ternak. In Teknologi Telur (2nd ed.). Ujung Pandang: Lephas.

Lestari, D., Riyanti, and Wanniatie, V. (2015). Pengaruh lama penyimpanan dan warna kerabang terhadap kualitas internal telur itik tegal. Jurnal Ilmiah Peternakan Terpadu Vol. 3(1): 7-14, 3(1), 1-7.

Onbaşilar, E. E., Poyraz, Ö., and Erdem, E. (2007). Effects of egg storage period on hatching egg quality, hatchability, chick quality and relative growth in Pekin ducks. Archiv Fur Geflugel kunde, 71(4), 187-191.

Purdiyanto, J., and Riyadi, S. (2018). Pengaruh lama simpan telur itik terhadap penurunan berat indeks kuning telur dan haugh unit. Maduranch, 3(1), 23-28.

Purwadi, Radiati, L., Evanuarini, H., and Andriani, R. (2017). Penanganan Hasil Ternak. In Penanganan Hasil Ternak. Malang: UB Press.

Raji, O., Aliyu, J., Igwebuike, J. U., and Chiroma, S. (2009). Effect of storage methods and time on egg quality traits of laying hens in a hot dry climate. ARPN Journal of Agricultural and
Biological Science, 4(4), 1-7.

Samli, H. E., Agma, A., and Senkoylu, N. (2005). Effects of storage time and temperature on egg quality in old laying hens. Journal of Applied Poultry Research, 14(3), 548-553. https://doi.org/10.1093/japr/14.3.548

Sekeroglu, A., and Altuntas, E. (2008). Effects of egg weight on egg quality charachteristics. Journal Science Food Agricultular, 89, 379-389.

Sekeroglu, A., Gök, H., and Duman, M. (2016). Effects of egg shell color and storage duration on the external and internal egg quality traits of atak-s layer hybrids. Ciencia e Investigación Agraria, 43(2), 15-15. https://doi.org/ 10.4067/s0718-16202016000200015

Septiana, N., Riyanti, and Nova, K. (2015). Pengaruh lama simpan dan warna kerabang telur itik Tegal terhadap indeks albumen, indeks yolk dan $\mathrm{pH}$ telur. Jurnal Ilmiah Peternakan, 3(1), 81-86.

Subari, Panggasa, Y., and Sutikno. (2013). Pengaruh lama penyimpanan telur itik Alabio (Anasplathyrinchos borneo) terhadap persentase daya tetas. Jurnal Pertanian Terpadu, 2(1), 1-10.

Sudaryani, T. (2003). Kualitas Telur. Jakarta: Penebar Swadaya.

Sulistina, L., Imanudin, O., and Falahudin, A. (2017). Pengaruh perendaman ekstrak teh hijau (Camellia sinesis) terhadap kualitas interior telur ayam Ras. Jurnal Ilmu Pertanian Dan Peternakan, 5(2), 198-203.

Swacita, I. B. N., and Cipta, I. P. S. (2011). Pengaruh sistem peternakan dan lama penyimpanan terhadap kualitas telur itik. Buletin Veteriner Udayana, 3(2), 91-98.

Ukwu, H. O., Ezihe, C. O., Asaa, S. K., and Anyogo, M. E. (2017). Effect of egg weight on external and internal egg quality traits of Isa Brown egg layer chickens in Nigeria. Journal Animal Science Veterinir Medic, 2, 126-132. 
Yuniwarti, E. Y. W., and Muliani, H. (2014). Status heterofil, limfosit dan rasio $\mathrm{H} / \mathrm{L}$ berbagai itik lokal di Provinsi Jawa Tengah. Jurnal Ilmu Ternak, 1(5), 22-27.
Yuwanta, T. (2004). Dasar Ternak Unggas. Yogyakarta: Kanisius. 